included in this issue discuss the breeding of shelduck at Magilligan, the status of the smew, the occurrence of a sea-horse off the coast of County Clare, and botanical notes. The Journal is published quarterly by a committee of naturalists under the editorship of Miss M. P. H. Kertland, the annual subscription being 10s. Copies may be obtained from $\mathrm{E}$. L. Calvert, Plant Pathology Field Station, New Forge Lane, Belfast.

\section{Use of the National Land Fund}

In the Budget debate in the House of Commons on April 15, Mr. H. Dalton made a number of proposals regarding the National Land Fund, from which the Chancellor of the Exchequer is proposing to take $\mathbf{£ 5 0}$ million. Mr. Dalton recapitulated the use which has been made of the Fund since it was created ten years ago to acquire properties which have been placed in the care of the National Trust and other suitable bodies; he urged that the Fund should be used on a much greater scale to prevent the destruction or spoiling of some of the better country and similar houses in Britain, and also wide areas of beautiful and often mountainous country, by placing them in the hands of some body which could be trusted to serve national as opposed to private interests. Specifically, he urged that the Fund should be used to provide the National Parks Commission with the finance it needs. The Chancellor agreed to study Mr. Dalton's suggestions, but observed that money for such purposes is in general best voted in Supply; in his view, it should be on the vote of a Minister and debated in the House of Commons.

\section{Thames Basin Archæological Observers Group}

Is London, Middlesex, Hertfordshire and Essex a group of archæologists, largely amateurs, has been formed to examine deposits in the Thames Basin area and thereby to prevent archæological and geological knowledge from being lost irrevocably through quarrying, building operations and various eivil engineering projects. Thus, gravels, 'peats', river terraces, cuttings and other doposits are being diligently examined, principally for Stone Age and Pleistocene remains. Members of the group have already begun sending details of finds, including Levallois flakes from near St. Albans, bones of a pachyderm from near West Hyde, a pagan Saxon split-socket spearhead from the Cheshunt area, and an Acheulean hand-axe of known provenance in the possession of a small boy at Croxley Green. Wherever possible, details of finds in private hands are being entered on cards. The group arranges lectures and outings for its members. Mr. A. D. Lacaille, author of the "Stone Age in Scotland" and an authority on the Stone Age in the Thames Valley area, has con. sented to be honorary adviser to the Thames Basin Archæological Observers Group, which has been affiliated to Group 10 of the Council for British Archrology. It is hoped that geologists, students of natural history and others will pass on information to the group's acting recorder, Francis Celoria, 519A Finchley Road, Hampstead, N.W.3.

\section{British Conference on Automation and Computa- tion}

THe rapid growth of the new industrial techniques known as automation, which also comprise computation, process control and data processing generally, and of the many persons likely to be affected by their application, has given rise to an urgent need for the establishment of some central organization to afford liaison between all the interested institutions. At the invitation of the Institution of Civil Engineers, the Institution of Mechanical Engineers and the Institution of Electrical Engineers, exploratory conferences were held on March 6 and April 16, as a result of which representatives of some twenty organizations with interests in the fields of automation and computation, including most of the major professional engineering and management institutes, approved proposals for closer collabora. tion, and agreed to recommend them to their Councils for adoption. The proposals, if accepted by the bodies concerned, will result in the setting up of a British Conference on Automation and Computation which will be organized in three groups of societies, having the following fields of interest: $(A)$ the engineering applications of automation techniques; $(B)$ the development and application of computers, automatic controls and programming techniques; $(C)$ the sociological and economic aspects of automation and computation procedures. At the exploratory conferences there was unanimous agreement that the setting up of a new and all-embracing society to be concerned with automation is not required, but that great advantage to Britain would ensue from the measures of collaboration now proposed, it being fully recognized that, in the framework of automation, the importance of the human side is equal to, if not greater than, that of the purely technological aspects. All societies and institutions interested in the subject will be welcome to support the activities of the conference by applying for membership of the appropriate group or groups. Further information can be obtained from the Secretary, Institution of Electrical Engineers, Savoy Place, W.C.2.

\section{Society of Indexers}

A NEW Society of Indexers, to encourage the publication of indexes, not only to books and periodicals but also to documents and archives, to improve the standard of indexing and to secure some measure of uniformity in technique, was founded at an inaugural meeting at the National Book League on March 30. The Society is to set up a panel of indexers specializing in various fields, from which authors, editors, publishers and others may be furnished with suitable names on application. It hopes to issue occasional papors and notes on indexing, and also to act as an advisory body on the qualification and remuneration of indexers. Membership of the Society is open to all bona fide indexers, librarians, cataloguers, arehivists and others interested in promoting its objects, on payment of an annual subscription of two guineas. Institutional membership is open to non-profitmaking organizations (two guineas) and other bodies (minimum of four guineas). Further details and forms of application for membership can be obtained from the Hon. Secretary, the Society of Indexers, 4 Fitzroy Street, London, W.1.

\section{National Museums of Southern Rhodesia}

THE annual report of the National Museums of Southern Rhodesia for 1955 records tho activities of the National Museum at Bulawayo and the Queen Victoria Museum at Salisbury. The most important work during the year has been the preparation of plans for the new museum building at Bulawsyo. The report also records that Lieut.-Colonel H. L. 